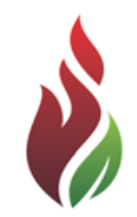

SUSTENERE

Publishing Corporation
REVISTA BRASILEIRA DE ADMINISTRAÇÃO CIENTIFICA

Journals Homepage:

www.sustenere.co/journals

\section{ASSÉDIO MORAL, ORGANIZAÇÕES E JUSTIÇA: ANÁLISE DE JULGADOS SOBRE ASSÉDIO MORAL NO TRIBUNAL SUPERIOR DO TRABALHO}

\section{RESUMO}

Na realização da atividade econômica praticada pelas organizações, muitas vezes, os gestores, ao exercerem o poder disciplinar, que é atribuído no Brasil por lei desde 1943, com a Consolidação das Leis Trabalhistas, extrapolam esse direito e atingem os direitos do empregado, também garantidos na legislação vigente. As atitudes hostis, como a deterioração proposital das condições de trabalho, o isolamento e a recusa de comunicação, os atentados contra a dignidade e o uso da violência verbal, física ou sexual - uma das modalidades do assédio moral que não será tratada nesta pesquisa - constituem os meios pelos quais o agressor atinge as vítimas do assédio moral. A coisificação do trabalhador é evidente em algumas organizações nas quais os empregados são tratados como peças substituíveis na engrenagem da produção, e não como seres humanos. O objetivo desta pesquisa consiste em analisar como os acórdãos proferidos pelo Tribunal Superior do Trabalho entre 2010 e 2012 identificam os conceitos e as características dos autores que tratam do assédio moral sofrido pelo empregado nas organizações. A metodologia adotada foi a pesquisa descritiva de cunho qualitativo. Os resultados comprovaram que o assédio moral faz parte do cotidiano das organizações, mas que o empregado está buscando na Justiça seu direito à dignidade da pessoa humana.

PALAVRAS-CHAVES: Assédio moral; Organizações; Tribunal Superior do Trabalho.

\section{BULLYING , ORGANIZATIONS AND JUSTICE : JUDGED ANALYSIS OF BULLYING IN THE SUPERIOR LABOR COURT}

\section{ABSTRACT}

On the realization of the economic activity practiced by the organizations, the managers often, when exercising disciplinary authority that has been assigned in Brazil by law since 1943, with the consolidation of labor laws, extrapolate this law and the employee rights that are also guaranteed in the legislation in force. Hostile attitudes such as the purposeful deterioration of working conditions, isolation and denial of communication, attacks against dignity, and the use of verbal, physical or sexual violence- one of the modalities of harassment that will not be treated in this research-constitute the means by which the attacker reaches the victims of harassment. The objectification of the worker is evident in some organizations where the employees are seen as replaceable parts in the production system and not as human beings. The objective of this research was to analyze how the verdicts delivered by the Labor Superior Court between 2010 and 2012 identify the concepts and the characteristics of the authors that deal the moral harassment suffered by the employee within organizations. The methodology adopted was the descriptive research of qualitative nature. The results proved that the harassment is part of the everyday life of the organizations. However, the employees are seeking in court their rights to obtain human dignity.

KEYWORDS: Moral Harassment; Organizations; Superior Labor Court.
Revista Brasileira de

Administração Científica,

Aquidabã, v.5, n.1, Jan, Fev, Mar, Abr, Mai, Jun 2014.

ISSN 2179-684X

SECTION: Articles

TOPIC: Responsabilidade

Socioambiental Corporativa

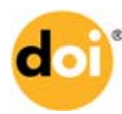

DOI: 10.6008/SPC2179-684X.2014.001.0015

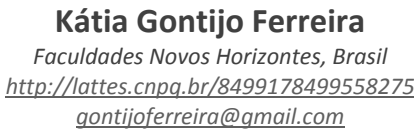

Fernando Coutinho Garcia

Faculdades Novos Horizontes, Brasil http://lattes.cnpq.br/4973183681192358 fernando.garcia@unihorizontes.br

Received: $18 / 12 / 2013$

Approved: 15/01/2014

Reviewed anonymously in the process of blind peer.

\section{Referencing this:}

FERREIRA, K. G.; GARCIA, F. C.. Assédio moral, organizações e justiça: análise de julgados sobre assédio moral no Tribunal Superior do Trabalho. Revista Brasileira de Administração Científica, Aquidabã, v.5, n.1, p.248-268, 2014. DOI:

http://dx.doi.org/10.6008/SPC2179$\underline{684 \times .2014 .001 .0015}$ 


\section{INTRODUÇÃO}

Nos últimos anos, muitos foram os estudos realizados que tiveram por objeto a análise da saúde do empregado no ambiente do trabalho. Alguns deles estão relacionados ao assédio moral, que é um fenômeno que reduz a pessoa a um estado de deterioração proposital das condições de trabalho. Isso acontece por parte de gestores despreparados que querem, a todo custo, aumentar a produtividade e os resultados.

Os empregados, sujeitos nessa relação de emprego, aparentemente, aceitam obedecer tudo que as organizações exigem, para se moldarem e aderirem ao sistema e a 'perda do poder real dos indivíduos na sociedade acontece no mesmo compasso que o domínio das organizações formais aumenta, o que as permite guiar a sociedade segundo seus interesses'. Como consequência fica o lado sombrio das organizações que resulta na má conduta dos seus gestores o que leva a violência no ambiente do trabalho. No desafio de ser sujeito dentro de uma organização, Siqueira e Mendes (2011), fazem uma crítica para que se possa rever a gestão de pessoas para a relação do homem como trabalho.

Freitas (2006), realiza um trabalho importante ao analisar a gestão contemporânea, que estaria doente. Ao trazer a indiferença de gestores frente à situação dos empregados e a indiferença em "planos ofensivos de demissões", a autora demonstra que o crescimento econômico não vem acompanhado da criação de mais vagas de empregos ou da redução da desigualdade social, dentro de uma gestão em que o lado humano fica em segundo plano.

O objetivo deste artigo é analisar os acórdãos proferidos pelo Tribunal Superior do Trabalho entre 2010 e 2012 para identificar os conceitos e as características dos autores que tratam do assédio moral sofrido pelo empregado nas organizações. O tema Assédio moral, analisado nos acórdãos da Justiça do Trabalho e tratado nesta pesquisa, pretende ser um instrumento de subsídios utilizado por empresários e gestores para melhorar a forma de administração no âmbito organizacional. Os resultados comprovaram que o assédio moral faz parte do cotidiano das organizações, mas que o empregado está buscando na Justiça seu direito à dignidade da pessoa humana.

\section{REFERENCIAL TEÓRICO}

As primeiras pesquisas sobre assédio moral no trabalho se iniciaram nos campos da Medicina e da Psicologia do Trabalho. Os três autores de grande relevância sobre o tema, Leymann (1990), Hirigoyen (2002) e Barreto (2006), publicaram seus trabalhos entre 1980 e 2000, em países diferentes. Os estudos iniciais sobre hostilidade no ambiente do trabalho, sob a ótica organizacional, são atribuídos a Heinz Leymann, responsável por introduzir o termo mobbing no universo trabalhista sueco, na década de 1980. 
A denominação assédio moral é de Hirigoyen, na França. No Brasil, esta nomenclatura foi introduzida por Margarida Barreto. Ressalta-se que os três são médicos e que eles começaram a pensar e analisar o tema a partir dos relatos de sofrimento laboral de seus pacientes e pesquisados. Segundo Guedes (2008),

[...] no começo de 1984 Heinz Leymann publica, num pequeno ensaio científico contendo uma longa pesquisa feita pelo National Board of Occupational Safety and Health in Stokolm, no qual demonstra as consequências do mobbing, sobretudo na esfera neuropsíquica, sobre a pessoa que é exposta a um comportamento humilhante no trabalho durante certo lapso de tempo, seja por parte dos superiores, seja por parte dos colegas (GUEDES, 2008).

A nomenclatura assédio moral começou a fazer parte do discurso dos trabalhadores brasileiros com o advento da Constituição Federal de 1988, que trouxe diversas disposições em defesa da pessoa humana. O termo dano moral está inserido em seu artigo $5^{\circ}$, inciso X. $\mathrm{O}$ fenômeno teve maior repercussão no meio acadêmico nacional após a defesa da dissertação de mestrado da médica Margarida Barreto, em 2000. Nesta pesquisa, realizada no Sindicato de Trabalhadores das Indústrias Químicas, Plásticas, Farmacêuticas, Cosmético e Similares de São Paulo, a autora tratou de analisar a jornada de humilhações dos empregados adoecidos no trabalho. A partir deste estudo, surgiram outras pesquisas acadêmicas sobre o tema, realizadas em outras categorias de trabalhadores, como a dos bancários. Esses sindicatos começaram a se mobilizar passado a interpor ações na Justiça do Trabalho, e a levar este termo para a análise dos magistrados, que, por sua vez, começaram a embasar seus julgados nos estudos realizados sobre o assédio moral.

Os autores que estudam o assédio moral, como Aguiar (2003), Barreto (2006), Freitas (2001), Garcia e Tolfo (2011), Guedes (2008), Heloani (2004), Hirigoyen (2002; 2011) e Leymann (1990), são unânimes em concluir que o fenômeno consiste em expor os empregados a situações humilhantes, constrangedoras, repetitivas e prolongadas durante a jornada de trabalho e no exercício de suas funções, sendo esta uma forma de coação cruel e desumana.

\section{Organizações e Poder Diretivo}

O ambiente de trabalho é para a grande maioria das pessoas o local onde se passa a maior parte do tempo. Muitas vezes, é lá também que elas depositam suas aspirações, sonhos e realizações pessoais (PELI \& TEIXEIRA, 2006). As empresas criam, de acordo com Freitas (2005), um espaço onde o trabalho, a convivência e os laços fraternos se tornam prazerosas, devendo ser compartilhados por todos os colaboradores. Os rituais estabelecidos na empresa são criados para ser vividos com emoção, não havendo espaço para os indiferentes. Ao analisar a cultura organizacional, Freitas (2005) coloca o indivíduo como o elo mais frágil da cadeia social, aquele que recebe todas as influências e choques que ocorrem nas instituições que o rodeia. Ele sofre os efeitos de todas as mudanças sociais que acontecem e "torna-se generalizada a ideia de que o indivíduo é hoje mais individualista" (FREITAS, 2005). 
Dejours (1992) analisa a pessoa em seu ambiente do trabalho, seja de forma individual ou coletiva. Ele aponta as consequências disso no trabalho e em sua vida no contexto social. Para o autor, é, "sobretudo individualmente que cada operário deve se defender dos efeitos penosos da organização do trabalho" (DEJOURS, 1992). O medo, segundo o autor, acompanha o trabalhador, que está sujeito aos riscos impostos pelo ambiente de trabalho:

[...] o grupo não somente efetua uma verdadeira seleção que garante o valor operacional de cada trabalhador que está no campo de obras, mas, por outro lado, defende-se do medo reavivado ao nível individual e ao nível coletivo pelo discurso e comportamento do medroso. [...] o enquadramento dos jovens trabalhadores, recém-chegados a uma equipe (DEJOURS, 1992).

A violência expressa no ambiente de trabalho nos dias atuais se fundamenta em uma sociedade:

[...] que vislumbra o capital, a economia como a fórmula mágica para todos os problemas em detrimento da própria dignidade da pessoa humana, termo, inclusive consagrado na Constituição Federal no Brasil de 1988, em seu art. $1^{\circ}$, III (BARRETO et al., 2009).

Toda pessoa goza de prerrogativas inerentes à sua qualidade de indivíduo com direitos de personalidade e de dignidade. A esfera de direitos que permeia a pessoa humana é inviolável, seja pelo Estado, seja pelos demais sujeitos de direito, que não podem violar a integridade psíquica e moral de outra pessoa (NOVELINO, 2009). A conduta nada ética de alguns gestores faz com que os empregados que sofrem assédio procurem cada vez mais o Poder Judiciário. Por isso, a Justiça do Trabalho apresenta em seus julgados o "reconhecimento de que o empregado passou por assédio moral, quando da realização de suas atividades contratadas" (COUTINHO, 2004, p.48).

O assédio moral na empresa agrega dois elementos essenciais à sua manifestação: o abuso de poder; e a manipulação perversa. Se, de um lado, o abuso de poder pode ser facilmente desmascarado, de outro, a manipulação insidiosa causa maior devastação. Peli e Teixeira (2006) defendem que o tratamento injusto e indigno por parte dos superiores hierárquicos pode causar danos irreparáveis à saúde dos trabalhadores. Fica evidente que, em um ambiente doentio e contaminado pela prática não combatida há graves consequências, como o aumento de empregados que se desmotivam que ficam estressados e que se tornam menos produtivos, o que gera enorme prejuízo para a organização.

Violado o direito, impõe-se como medida educativo-punitiva a indenização ao empregado, por danos tanto materiais quanto morais. E não se deve "banalizar o assédio fazendo dele uma fatalidade de nossa sociedade. Ele não é consequência da crise atual, é apenas um derivado de um laxismo organizacional" (HIRIGOYEN, 2002). Para Heloani, o assédio moral "caracteriza-se pela intencionalidade. Consiste em constante e deliberada desqualificação da vítima, seguida de sua consequente fragilização, com o intuito de neutralizá-la em termos de poder" (HELOANI, 2004). 
Nas organizações as pessoas se pautam muito mais pelo aspecto legal que pelo moral. O assédio moral ocorre, pois encontra um terreno fértil, pois seus autores não encontram maiores resistências nas organizações, ou ainda, reprovações ou regras que possa punir ou impedir esse mal (BARRETO et al., 2009).

O assédio moral no trabalho está se tornando uma prática cada vez mais comum no atual contexto mundial. Segundo Elgenneni e Vercesi (2009), para existir o assédio moral é preciso haver repetitividade e intencionalidade, elementos que caracterizam a ocorrência do fenômeno e que o diferencia das agressões psicológicas pontuais e dos conflitos nas relações interpessoais. Apesar de o empregador ter o poder diretivo já a partir do momento que contrata o empregado, também conhecido como "poder de comando", o empregador não pode entender esse comando sem restrições impostas. Há separação possível entre a força de trabalho e o homem que trabalha, inclusive pela Constituição da República de 1988, em seu artigo $7^{\circ}$ :

[...] são direitos dos trabalhadores urbanos e rurais, além de outros que visem à melhoria de sua condição social: I - relação de emprego protegida contra despedida arbitrária ou sem justa causa, nos termos de lei complementar, que preverá indenização compensatória, dentre outros direitos (BRASIL, 1988).

Todavia, existe por parte de alguns empregadores, ou de quem está no poder diretivo do empregado, a utilização desse comando de forma negativa, abalando, física e emocionalmente, a estrutura do empregado. O assédio [...] expressaria o sentido de insistência impertinente, perseguição, pretensão constante em relação a alguém [...] (COUTINHO, 2004):

Para realizar o poder diretivo sem se utilizar do assédio moral, o Direito brasileiro prevê sanções disciplinares, que se traduzem em advertência/repreensão, suspensão e, até, dispensa do empregado por justa causa. Porém, não são admitidas pela legislação trabalhista brasileira a multa salarial e a transferência punitiva. Contudo, poderá o empregador suspender o empregado das atividades. (COUTINHO, 2004).

[...] limitada a 30 dias consecutivos, conforme o art. 474 da CLT. Expedido esse período, tem-se o exercício abusivo do poder disciplinar pelo empregador, importando em motivo para a despedida indireta pelo empregado (GARCIA, 2010):

A finalidade das sanções disciplinares é restabelecer o equilíbrio na execução do
trabalho, permitindo que a empresa atinja os seus fins. Uma das condições de sua
aplicação é a imediatidade. Falta não punida em lapso de tempo razoável
presume-se perdoada (perdão tácito) e não poderá ser invocada em momento
posterior, como justificativa para qualquer sanção. O empregador somente está
autorizado a aplicar advertência, suspensão e dispensa por justa causa se tiver
embasamento legal. A dispensa por justa causa é aplicada tendo em vista a falta
disciplinar cometida pelo empregado (GARCIA, 2010).

Para aplicar a dispensa por justa causa, o empregador cumpre regras taxativas e que somente podem ser aquelas descritas no art. 482 da CLT, como: ato de improbidade, incontinência de conduta ou mau procedimento, negociação habitual, por conta própria ou alheia, sem permissão do empregador, condenação criminal do empregado, passada em julgado, caso não tenha havido a suspensão da execução da pena, desídia, embriaguez habitual ou em serviço, violação de segredo de empresa, ato de indisciplina ou insubordinação, ato lesivo contra a honra e 
a boa fama ou ofensas físicas contra empregador e superior hierárquico, salvo em caso de legítima defesa, prática de jogos de azar e atos atentatórios à segurança nacional (BRASIL, 1943; SCHWARZ, 2007).

Qualquer outra forma de punição pode levar à indenização por dano moral, descrita no artigo $5^{\circ}, \mathrm{X}$, da Constituição da República de 1988, que determina ser inviolável a vida privada, a intimidade, a honra e a imagem das pessoas. Caso haja violação desses preceitos, é assegurada a indenização pelo dano material e moral (NOVELINO, 2009). Diretamente proporcional ao poder de punição do empregador, o empregado poderá não cumprir e resistir caso as ordens atentem contra sua pessoa, sua honra, sua intimidade ou sua dignidade. O dever de obediência do empregado está ligado a uma obrigação contratual. Seria atentatório à dignidade do ser humano obedecer à ordem fora dos limites da destinação econômica da prestação do trabalho. Essa dignidade também é constitucional e está no art. $1^{\circ}, \mathrm{III}, \mathrm{CF} / 88$, como fundamento do estado democrático brasileiro (SCHWARZ, 2007).

Quando há por parte de quem dirige ou comanda os negócios da empresa uma atitude perversa para com seus subordinados, ocorre um conflito que pode levar a ações judiciais para o ressarcimento do dano moral ou assédio moral sofrido durante o contrato de trabalho:

$O$ assédio é sempre resultante de um conflito. Resta saber se esse conflito provém do caráter das pessoas nele envolvidas, ou se está inscrito na própria estrutura da empresa. Nem todos os conflitos degeneram em assédio. Para que isso aconteça, é preciso conjunção de vários fatores: desumanização das relações de trabalho, onipotência da empresa, tolerância ou cumplicidade para com os indivíduos perversos (HIRIGOYEN, 2002).

Os assalariados são sempre vítimas de desconsiderações por parte de quem gerencia que podem influenciar negativamente sua autoconfiança (HIRIGOYEN, 2011). Comprovada a ocorrência do assédio moral, devem ser indenizados os danos dele advindos. O assédio moral do empregador consiste no uso indevido do poder diretivo sobre o empregado que está sob suas ordens. O empregado pode sofrer sanções, desde que previstas na Consolidação das Leis Trabalhistas (CLT), conforme o art. 482 e incisos subsequentes. Outras sanções podem ser consideradas assédio moral (GARCIA, 2010). O empregado que se sentir lesado pela conduta do empregador poderá pedir a rescisão do contrato de trabalho de forma indireta. Isso significa que poderá dar justa causa ao empregador e receber todas as verbas trabalhistas como se tivesse sido mandado embora da empresa. A garantia legal está descrita no artigo 483 da CLT.

\section{Os Perfis do Agressor e da Vítima}

Como autor do assédio moral, há o assediador, que pretende demonstrar seu poder e controle de forma perversa e continuada, sem qualquer culpabilidade, atingindo a dignidade e a integridade psíquica e física do assediado. Hirigoyen (2002) situa o assediador como a perversão narcísica, sendo uma estratégia utilizada para destruir o outro, a vítima assediada. "Um perverso narcisista só se estrutura satisfazendo plenamente suas pulsões destrutivas". Hirigoyen (2002) 
refere-se à vítima como aquela escolhida pelo perverso. Ela "torna-se bode expiatório, responsável por todo o mal. Será daí em diante o alvo da violência, evitando a seu agressor a depressão ou o questionamento". A vítima é inocente do crime pelo qual vai pagar. O que importa para o assediador é conservar o poder e controlar a situação. Para estabelecer este enredamento, utiliza procedimentos ilusórios de comunicação. Isso não é feito para criar ligações, mas sim para afastar e impedir o intercâmbio. Todas as estratégias são utilizadas para desqualificar o outro. $O$ agressor, dentro da empresa, difunde boatos que vão ferir a vítima, mas ela, geralmente, não ousa atacar o perverso.

A segunda fase, da violência manifesta, surge quando a vítima reage, tornando seu ódio visível, num momento em que a vítima dá a impressão de escapar do perverso:

É uma fase de ódio em estado puro, extremamente violenta, feita de golpes sujos e de injúrias, de palavras que rebaixam, humilham, atingem com seu escárnio tudo que pertence exclusivamente ao outro. Essa armadura de sarcasmo protege o perverso do que mais teme - a comunicação (HIRIGOYEN, 2002).

Assim, "não conseguir levar os outros a usarem de violência é para o perverso um fracasso, e, portanto, um meio de bloquear a propagação do processo" (HIRIGOYEN, 2002, p.138). As consequências da implantação desses processos descritos podem ser funestas para a vítima. A vítima apenas assim se qualifica porque foi escolhida pelo perverso. De acordo com Hirigoyen (2002), ela é inocente do crime pelo qual vai pagar, mas há quem desconfie dela. A vítima não tem como agir, por não ter forças para atuar de outra forma, pois a característica do perverso é ter em mira as partes vulneráveis do outro, 'o ponto em que há debilidade ou uma patologia. Todo indivíduo apresenta um ponto fraco, que se tornará para o perverso o ponto a ser atacado'. Em verdade, a vítima não é masoquista ou depressiva, nem é cúmplice do seu agressor.

\section{Contrato de Trabalho: Definições de Empregado e de Empregador}

O trabalho não se confunde com o emprego. Para todo o trabalho haverá um trabalhador, mas nem sempre haverá um empregado. Para que este exista, faz-se mister a existência de um empregador, que delega, por meio de um contrato, parte da cadeia de produção de bens e/ou serviços, mediante remuneração e subordinação a suas ordens patronais (MARTINS PINTO, 2004).

Como a proposta deste estudo é analisar os julgados pelo Tribunal Superior do Trabalho nas decisões sobre assédio moral, fazem-se necessária identificar as definições de empregado e de empregador delimitadas na Consolidação das Leis Trabalhistas (CLT). Nos termos do art. $3^{\circ}$ da CLT, 'considera-se empregado toda pessoa física que prestar serviço de natureza não eventual a empregador, sob a dependência deste e mediante salário' (BRASIL, 1943).

Acrescenta Saraiva (2009) que o contrato de trabalho é uma [...] relação típica de trabalho subordinado a denominada relação de emprego, em que se encontram presentes os requisitos caracterizados do pacto laboral, sendo, nos dias atuais, a mais comum e importante relação de 
trabalho existente (SARAIVA, 2004). O empregador, nos termos do art. $2^{\circ}$, caput, da Consolidação das Leis Trabalhistas (CLT), é considerado "a empresa, individual ou coletiva, que, assumindo os riscos da atividade econômica, admite, assalaria e dirige a prestação pessoal de serviços" (BRASIL, 1943).

A relação de emprego significa o "vínculo empregatício existente entre empregado e empregador. Trata-se, assim, do contrato individual de trabalho" (GARCIA, 2010). O contrato individual de trabalho é o vínculo que se realiza entre empregado e empregador, sendo que o empregado é somente pessoa física. O conceito de contrato de trabalho está descrito no art. 442 da Consolidação das Leis Trabalhista como "[...] o acordo tácito ou expresso correspondente à relação de emprego" (GARCIA, 2010). Portanto, o consentimento a que se refere o artigo pode ser expresso ou subentendido, Isso significa que não é necessário escrever um contrato de emprego para as pessoas assinarem para ter validade. Ele pode ser verbal ou tácito, bastando para isso uma pessoa começar a prestar serviço para a outra com as características de relação de emprego.

As partes no contrato são obrigadas a cumprir os ajustes estabelecidos: "está o empregado submetido ao poder hierárquico e disciplinar do empregador. Fica, portanto, subordinado ao empregador" (MARTINS PINTO, 2004). O contrato gera entre as partes o princípio da probidade e o da boa-fé. Não pode o empregado deixar, por exemplo, de observar as normas de segurança. Ele deve ser diligente, pontual e zelar pelo bom andamento do serviço prestado. Também tem que guardar sigilo, se o contrato o exigir, e não pode concorrer com o empregador em suas atividades. Barros (2005) define que a relação de emprego tem natureza contratual exatamente porque é gerada pelo contrato de trabalho. Os principais elementos desta relação são:

a) Pessoalidade - um dos sujeitos (o empregado) tem o dever jurídico de prestar os serviços em favor de outrem pessoalmente.

b) Natureza não eventual do serviço - ele deverá ser necessário à atividade normal do empregador.

c) Remuneração do trabalho - a ser executada pelo empregado.

d) Subordinação jurídica da prestação de serviços ao empregador.

Constata-se, portanto, que somente a relação de emprego estará sujeita ao contrato de trabalho regido pela CLT e, consequentemente, ao assédio moral. Por isso, em caso de descumprimento das normas por parte dos gestores, poderá o empregado recorrer à Justiça do Trabalho.

\section{As Diferentes Relações de Assédio Moral na Organização}

O assédio moral, que pode vir a ser praticado por chefes mediatos e imediatos, bem como por colegas de trabalho, uma vez que estes devem estar sob o comando do empregador, atinge o aspecto psicológico do empregado, que sofre uma pressão muito grande, afetando diretamente 
seu ritmo de produção. A vítima, além sofrer com o assédio por algum motivo referente ao trabalho, começa a ser cobrada e assediada também pela queda de produção. Com o decorrer do tempo, passa a sofrer pressão interna para pedir demissão ou dispensa da função exercida (BARRETO, 2006; FREITAS, 2001, 2007; GUEDES, 2008; HIRIGOYEN, 2002, 2011).

Em uma primeira análise, pode parecer que o assédio moral somente é praticado de cima para baixo isto é, de um superior para um subordinado. Apesar de ser o mais corriqueiro, não é exclusivo. Hirigoyen (2002; 2011), a partir de um aprofundado estudo do assédio moral no ambiente laboral, correlacionou suas principais configurações com suas motivações. Existem diferentes tipos de assédio moral. O mais comum é aquele denominado 'assédio vertical'. Verificase o assédio moral de tipo vertical durante a execução do contrato de trabalho quando a violência psicológica é praticada de cima para baixo, deflagrada pela direção da empresa ou por um superior hierárquico contra o empregado (GUEDES, 2008).

Ele acontece nas hierarquias autoritárias, onde predominam condutas negativas, relações desumanas e aéticas de longa duração, dirigidas por um ou mais chefes a um subordinado, desestabilizando-o em relação ao ambiente de trabalho e à própria organização. Para Hirigoyen (2002), quando um superior agride um subordinado há consequências muito mais graves à saúde dela do que quando o subordinado é agredido pelos próprios colegas de trabalho. Neste caso, a vítima se sente enganada por todos que assistem às agressões contínuas sem interferir [...] pois a chefia raramente propõe uma solução direta [...]. A solução proposta é, na melhor das hipóteses, uma mudança para o outro posto, sem que se pergunte se o interessado está de acordo (HIRIGOYEN, 2002).

A agressão é clara, pois um superior hierárquico esmaga seus subordinados com seu poder. É um modo de aquele pequeno chefe valorizar-se. A principal característica deste tipo de assédio é seu caráter excludente, utilizado pela hierarquia como elemento principal na relação entre o agressor e a vítima. $O$ assédio horizontal envolve uma perseguição realizada pelos próprios colegas de trabalho. Guedes relaciona o assédio horizontal a um tipo de perversão que pode decorrer da competitividade e, também:

[...] da preferência pessoal do chefe - porventura gozada pela vítima a inveja, o preconceito racial, a xenofobia, razões políticas ou religiosas, a intolerância pela opção sexual ou o simples fato de a vítima ser ou comportar-se de modo diferente do conjunto dos colegas. Essa forma de psicoterror tanto ocorre de forma individual quanto coletiva (GUEDES, 2008).

Para Guedes (2008), entre os tipos de assédio moral destaca-se um totalmente improvável e de difícil aceitação, devido à sua originalidade. Trata-se do assédio moral ascendente, que se caracteriza por ser exercido pelo subordinado em relação a seu superior hierárquico. Uma de suas características pode ser entendida como:

[...] a violência de baixo para cima geralmente ocorre quando um colega é promovido sem a consulta dos demais, ou quando a promoção implica um cargo de chefia, cujas funções os subordinados supõem que o promovido não possui méritos para desempenhar (GUEDES, 2008). 
Hirigoyen (2011) explica que as vítimas "não sabem para onde se dirigir para se defender". O Caso de Eva, descrito por Leymann (1990), é considerado o primeiro caso de mobbing descrito pela literatura. $\mathrm{O}$ assédio ascendente é mais difícil, pois o poder diretivo do empregador e seus gerentes é mais evidente. Contudo, "não obstante a insignificância estatística do mobbing ascendente, a crueldade da violência praticada não é menor do que aquela verificada nos demais tipos" (GUEDES, 2008). No assédio misto, segundo Hirgoyen (2011), é necessário identificar quem é o principal agressor. Ocorre quando o subordinado é agredido, simultaneamente, por superior e colegas. "A pessoa passa a ser considerada responsável por tudo que dê errado. Bem depressa ninguém mais a suporta e, mesmo que alguns não sigam a opinião do grupo, não ousam denunciar" (HIRIGOYEN, 2011).

Corrêa e Carrieri (2005) pesquisaram o caso de assédio moral em que as vítimas não aceitaram os desmandos do superior hierárquico e resolveram denunciá-lo à Justiça do Trabalho. Os autores atribuem o crescimento do número de pesquisas sobre o tema às próprias demandas constantes nas organizações, que exigem do trabalhador maior produtividade e cumprimento de metas. No ambiente de trabalho, tornaram-se constantes as queixas dos trabalhadores, configurando desde a simples dificuldade de relacionamento com os colegas e com as chefias até a ocorrência de perseguição e discriminações que caracterizam o assédio moral. $O$ trabalhador busca, cada vez mais, seus direitos, sejam nas discussões no próprio ambiente de trabalho, seja no Poder Judiciário, por meio de ações trabalhistas, para garantir seus direitos (CAIXETA, 2010; HELOANI, 2004).

Todos esses reflexos negativos levaram os trabalhadores humilhados e discriminados dentro das organizações a buscar seus direitos na Justiça do Trabalho. Com isso, as ações de dano moral e de assédio moral cresceram, e os muitos julgados estão sendo embasados nos autores de referência de estudos sobre o tema na Administração (CAIXETA, 2010; GUEDES, 2008).

\section{METODOLOGIA}

O estudo proposto teve cunho descritivo, pois a pesquisa procurou identificar e descrever a configuração do assédio moral nas relações de trabalho nos julgados realizados nos acórdãos do Tribunal Superior do Trabalho. De acordo com Vergara (2005), a pesquisa descritiva expõe as características de determinado fenômeno e pode estabelecer correlações entre variáveis e definir sua natureza. $\mathrm{Na}$ análise, não há "compromisso de explicar os fenômenos que descreve, embora sirva de base para tal explicação" (VERGARA, 2005).

Teve ainda o objetivo de conhecer as diversas situações que ocorrem na vida social, política e econômica enfim, em todos os aspectos do comportamento humano. Nesse contexto, o indivíduo pode ser tomado isoladamente ou em grupos e comunidades mais complexas. Segundo 
Cervo e Bervian (2006), "a pesquisa descritiva observa, registra, analisa e correlaciona fatos ou fenômenos (variáveis) sem manipulá-los".

Quanto aos meios de investigação, optou-se pela pesquisa documental. Ou seja, a estratégia da pesquisa teve como principal fonte de consulta à análise das decisões judiciais proferidas no Tribunal Superior do Trabalho, o que permitiu uma melhor compreensão do fenômeno assédio moral nas organizações. Vergara (2005) acrescenta que a investigação documental é aquela

[...] realizada em documentos conservados no interior de órgãos públicos e privadas de qualquer natureza ou com pessoas: registros, anais, regulamentos, circulares, ofícios, memorandos, balancetes, comunicações informais, filmes, microfilmes, fotografias, videoteipe, informações em disquete, diários, cartas pessoais e outros (VERGARA, 2005).

Os documentos jurídicos, fonte desta pesquisa, constituem uma fonte 'rica de informes do ponto de vista sociológico, mostrando como uma sociedade regular o comportamento de seus membros e de que forma se apresentam os problemas sociais' (LAKATOS \& MARCONI, 2007). As unidades de análise podem ser palavras, 'expressões, frase, parágrafo', ou, ainda, o conteúdo que se apoia em procedimentos estatísticos ou interpretativos. No caso desta pesquisa, utilizou-se a análise interpretativa dos julgados proferidos no TST (VERGARA, 2006).

A estratégia da pesquisa teve como principal fonte de consulta a análise das decisões judiciais proferidas no Tribunal Superior do Trabalho, maior instância da Justiça Especializada Trabalhista no Brasil. Por isso, a opção pela exploração de julgados nesta instância superior permitiu uma compreensão mais detalhada do fenômeno 'assédio moral', dos conceitos utilizados e dos autores que estão sendo embasados nos julgados proferidos pelos ministros do TST (VERGARA, 2006).

Gil (2009) descreve a análise da pesquisa documental como sendo aquela que "vale-se de materiais que não receberam ainda um tratamento analítico ou que ainda podem ser elaborados de acordo com os objetivos da pesquisa". A coleta da amostra de dados foi feita por meio de pesquisa no endereço eletrônico do TST e em publicações especializadas sobre o tema na Administração. Os acórdãos foram interpretados com base na visão dos ministros que julgaram as causas de assédio moral e nas teorias desenvolvidas pelos estudiosos do tema apresentadas no referencial teórico e reconhecidos como prática de assédio moral nas organizações (CAIXETA, 2010).

Para o desenvolvimento deste estudo adotou-se a análise de conteúdo, pois é necessário descrever como os ministros do Tribunal Superior do Trabalho interpretaram o assédio moral, com embasamento nas teorias desenvolvidas pelos estudiosos do tema apresentadas no Referencial Teórico (CAIXETA, 2010). Ao conceituar o tema, Bardin (2006) o associa a "um conjunto de técnicas de análise das comunicações". Para a autora, essa técnica das comunicações é utilizada pelo investigador para que ele possa reconhecer, por meio de procedimentos sistemáticos e objetivos da descrição do conteúdo das mensagens analisadas, quais seriam os indicadores, tanto qualitativos quanto quantitativos. Nesse sentido, Bardin (2006) acrescenta que o "analista é como 
um arqueólogo. Trabalha com vestígios: os documentos que pode descobrir ou suscitar. Mas os vestígios são a manifestação de estados, de dados e de fenômeno". Neste último, enquadra-se o fenômeno "assédio moral", objeto deste estudo.

\section{RESULTADOS}

O fenômeno do assédio moral é uma questão organizacional, um psicologismo pervertido que expõe traços patológicos da cultura empresarial, que tem como metas a competição, o abuso de poder e, até mesmo, a manipulação perversa de pessoas, que são eleitas vítimas (DEJOURS, 1992). Os conceitos descritos pelos autores que tratam do fenômeno, como Aguiar (2003), Barreto (2006), Freitas (2001), Garcia e Tolfo (2011), Guedes (2008), Heloani (2004), Hirigoyen (2002; 2011), Leymann (1990), dentre outros, podem ser abstraídos das decisões a seguir.

[..] Já o assédio moral (mobbing, bullying, harcèlement moral ou, ainda, manipulação perversa, terrorismo psicológico, caracteriza-se por ser uma conduta abusiva, de natureza psicológica, que atenta contra a dignidade psíquica, de forma repetitiva e prolongada, e que expõe o trabalhador a situações humilhantes e constrangedoras, capazes de causar ofensa à personalidade, à dignidade ou à integridade psíquica, e que tenha por efeito excluir a posição do empregado no emprego ou deteriorar o ambiente de trabalho, durante a jornada de trabalho e no exercício de suas funções. Processo: AIRR - 19800-29.2010.5.14.0008 Data de Julgamento: 05/09/2012, Relator Ministro: Aloysio Corrêa da Veiga, 6a Turma, Data de Publicação: DEJT 14/09/2012.

Pode-se deduzir ainda dos julgados que o assédio moral na empresa agrega dois elementos essenciais à sua manifestação: o abuso de poder e a manipulação perversa. Se, de um lado, o abuso de poder pode ser facilmente desmascarado, a manipulação insidiosa causa maior devastação (BARRETO, 2006; GUEDES, 2008; HIRIGOYEN 2002, 2011). O fenômeno se instala de modo quase imperceptível. Inicialmente, a vítima se descuida, encarando o fato como simples brincadeira. Todavia, é na repetição dos vexames das humilhações que a violência vai se mostrando demolidora. Se ninguém de fora intervier energicamente, evolui numa escala destrutiva. Guedes (2008) descreve esse abuso como psicoterror, no qual a vítima é presa numa armadilha sem saber por quê.

[...] O assédio moral no trabalho consiste no comportamento contínuo e premeditado de intensa violência psicológica de uma ou mais pessoas contra outra no local de trabalho, pretendendo aniquilá-la emocionalmente para afastá-la do convívio profissional, seja forçando-a a pedir demissão, aposentadoria precoce ou transferência do setor em que labora. Segundo Márcia Novaes Guedes, no âmbito laboral, o assédio moral ou mobbing revela-se em "atos comissivos ou omissivos, atitudes, gestos e comportamentos do patrão, da direção da empresa, de gerente, chefe, superior hierárquico ou dos colegas, que traduzem uma atitude contínua e ostensiva perseguição que possa acarretar danos relevantes às condições físicas, psíquicas, morais e existenciais da vítima." Os elementos caracterizadores do fenômeno são, portanto, a gravidade da conduta, sua perpetuação no tempo, a finalidade específica de desestruturar emocionalmente o empregado tencionando seu afastamento, e o efetivo dano psíquico. Esta última característica reveste-se em enfermidade psicológica diagnosticada clinicamente, gerada ou agravada em razão do comportamento pernicioso Processo: AIRR 38200-24.2009.5.22.0002 Data de Julgamento: 21/11/2012, Relatora Ministra: Delaíde Miranda Arantes, $7^{\text {a }}$ Turma, Data de Publicação: DEJT 23/11/2012. 
Na empresa, a evolução do conflito se verifica em face da completa inoperância dos seus dirigentes, seja por falta de habilidade de seus administradores para lidar com os empregados subordinados, seja pelo conforto da indiferença, seja pelo fato de a empresa tirar proveito dessa situação estressante e acreditar neste tipo de procedimento como método eficaz para obrigar os assalariados a produzirem mais.

[...] No caso concreto, o quadro fático evidencia que a reclamada, ao impor à reclamante restrições ao uso do banheiro, como prévia autorização, controle do número de idas e do tempo de permanência, sob pena de prejudicar a produção da empresa, exorbitou os limites de seu poder diretivo e disciplinar, em evidente situação antijurídica de abuso de direito. Tal procedimento cerceia a liberdade individual do trabalhador de satisfazer suas necessidades fisiológicas, além de expô-lo à constante situação vexatória e humilhante, que, ao fim, acaba por comprometer o próprio resultado empresarial almejado, configurando dano moral passível de ressarcimento. Processo: RR - 51300-65.2007.5.20.0004 Data de Julgamento: 08/02/2012,Relator Ministro: Walmir Oliveira da Costa, $1^{\text {a }}$ Turma, Data de Publicação: DEJT 10/02/2012.

As atitudes advindas do comportamento de chefias (assédio vertical descendente), tais como exigência de metas inatingíveis (em demasia e urgência desnecessária), críticas e humilhações reiteradas, com a finalidade de exclusão do empregado, evidenciam a ocorrência deste tipo de assédio moral. Segundo Marie-France Hirigoyen (2002; 2011), aqueles que abusam do poder, que agridem e os responsáveis pelo assédio moral no trabalho tentam passar uma imagem da vítima que não é real. A vítima, seja homem ou mulher, não é frágil, não é neurótica, não tem mau caráter, não é de difícil convivência e não é profissionalmente incompetente. Contudo, sofre assédio moral descendente, ou vertical, um dos mais comuns, como se verifica nas decisões.

[...] A hipótese em exame tipifica, sem dúvida alguma, o chamado assédio descendente ou vertical, que se caracteriza pelo abuso de direito do empregador, diretamente, ou pelo superior hierárquico, no exercício, por delegação, dos poderes diretivo e disciplinar. Dúvida não há, também, de que a conduta ilícita do gerente regional da Reclamada provocou sofrimento moral no reclamante, consubstanciado, sobretudo, com a cobrança desrespeitosa de ações dirigidas no sentido da incrementação dos negócios comerciais, acarretando, ao obreiro, ofensa à sua dignidade, à sua integridade psicológica, sendo devida a reparação pertinente. Processo: AIRR - 15000-72.2009.5.08.0003 Data de Julgamento: 30/05/2012, Relatora Ministra: Maria de Assis Calsing, $4^{\text {a }}$ Turma, Data de Publicação: DEJT 01/06/2012.

Os ministros adotam o conceito de assédio moral utilizado pelos autores que embasam o tema, quais sejam: os abusos cometidos pelos gestores diretos, que deveriam ter tomado alguma providência para cessar o fenômeno, e não o fizeram (GUEDES, 2008; HIRIGOYEN, 2002, 2011)

[...] Mobbing ou assédio moral, embora implique uma violação da intimidade do trabalhador, é algo muito mais grave. Enquanto a violação a intimidade decorre do uso abusivo do poder diretivo do empregador, muitas vezes exagerando no uso de certas práticas voltadas para proteção do patrimônio da empresa, o assédio moral, na realidade, decorre de atitude deliberada de um perverso cujo objetivo é destruir a vítima e afastá-la do mundo do trabalho. Para a vitimóloga Marie-FranceHirigoyen, entende-se por assédio moral no local do trabalho "toda e qualquer conduta abusiva manifestando-se sobretudo por comportamento, palavras, atos, gestos, escritos que possam trazer dano à personalidade, à dignidade, à integridade física ou psíquica de uma pessoa, pôr em perigo seu emprego ou degradar o ambiente de trabalho". Processo: AIRR - 34340-61.2008.5.06.0142 
Data de Julgamento: 16/02/2011, Relator Ministro: Luiz Philippe Vieira de Mello Filho, $1^{\text {a }}$ Turma, Data de Publicação: DEJT

Ressalta-se que o empregado pode sofrer assédio moral horizontal e vertical. No caso horizontal, os grupos tendem a nivelar os indivíduos e a não suportar as diferenças, seja de sexo, raça ou religião. Em um grupo tradicionalmente reservado aos homens não é fácil para uma mulher chegar e se fazer respeitar. Ela está sujeita a piadas grosseiras, gestos obscenos, desdém a respeito do que diz e faz, e recusa em ter o seu trabalho levado a sério.

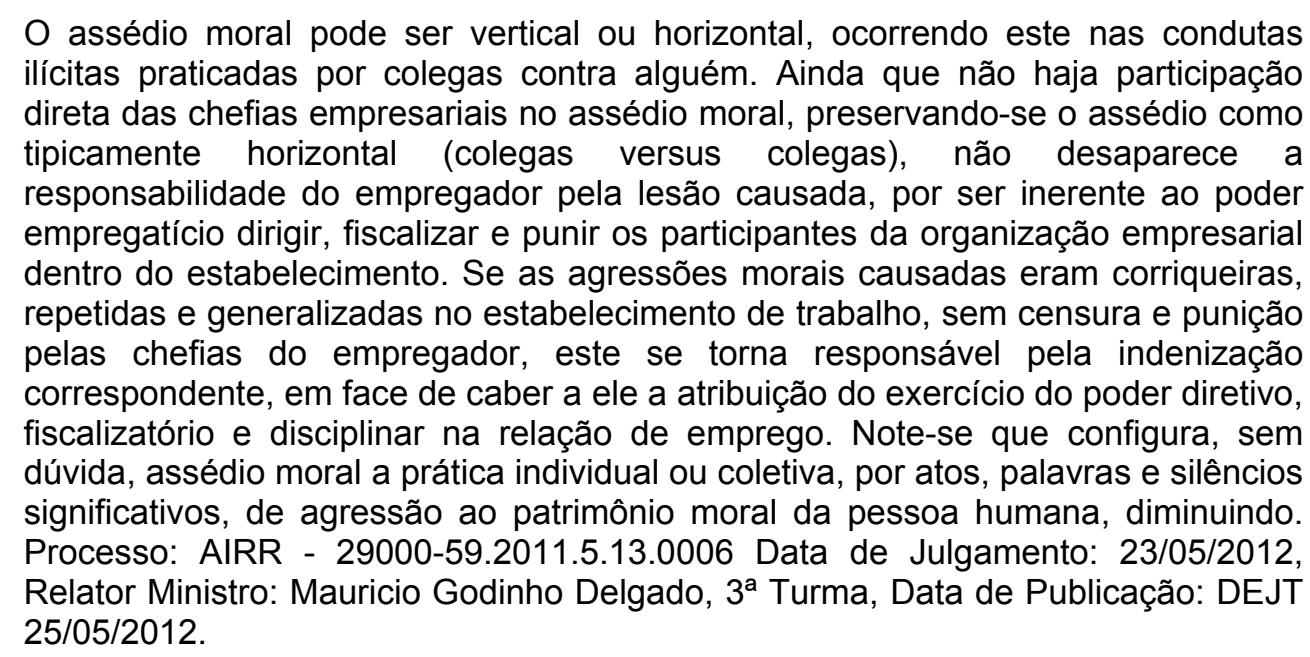

Violado o direito, impõe-se como medida educativo-punitiva a indenização ao empregado, por danos tanto materiais quanto aos morais.

No caso dos autos, o assédio moral sofrido pelo autor está evidenciado em todos os seus elementos, sendo que "houve, ainda, prolongamento no tempo já que não foi uma única situação que envolveu o autor". Restou demonstrado, conforme a sentença, que o procedimento adotado pela empresa demandada "gerou constrangimento e humilhação para o trabalhador, diante da situação vexatória a que estava exposto, sem contar que extrapola (em muito) a moderna concepção do poder de comando do empregador."(fls.127-8).(...).e concluiu que a reclamada adotou conduta inadequada para com o reclamante ao expor o obreiro a situação vexatória, causando humilhação e constrangimento, o que configura assédio moral. Processo: AIRR - 65240-53.2007.5.04.0292 Data de Julgamento: 10/02/2010, Relator Ministro: Luiz Philippe Vieira de Mello Filho, $1^{\text {a }}$ Turma, Data de Publicação: DEJT 26/02/2010.

Garcia \& Tolfo (2011) acrescentam que assédio moral significa violência no trabalho, assumindo condição psicológica. É um tipo de violência moral praticado no ambiente de trabalho. $O$ assédio moral traz o aspecto de inferioridade da vítima, que tem abalada toda a sua estrutura pessoal, pois o assédio é um ato contínuo, que vai degradando a pessoa e minando suas forças (VELÁSQUEZ, 2002).

Conforme Bernardes \& Marcondes (2010) há na própria organização a hierarquia em níveis de coordenação. Na linha de comando, ela é coordenada por um supervisor, que, por sua vez, é coordenado por um gerente, até chegar ao presidente da empresa. Esses níveis podem estabelecer conflitos de competitividade que, segundo as decisões analisadas nesta pesquisa, é uma das explicações para que uma pessoa transforme a vida da outra num verdadeiro infortúnio, que é o assédio moral. 
Nos relatos dos julgados analisados, vislumbram-se claramente os aspectos gerenciais negativos para as organizações. Observa-se que não é qualquer conduta mais enérgica por parte dos administradores ou dos empregadores que dará ensejo à caracterização do assédio moral. Ele somente se caracteriza como assédio moral em situações específicas, já definidas neste estudo, como sua continuidade em relação à vítima, que causa verdadeiro trauma a ela, "a humilhação rompe temporalidades, reforça o sentimento de inutilidade, comprometendo a identidade e a dignidade." (BARRETO, 2006, p.168).

Os ensinamentos dos teóricos que tratam do tema 'Assédio moral' estão sendo utilizados de forma precisa para o embasamento dos acórdãos proferidos pelo Tribunal Superior do Trabalho, advindos dos conceitos, características e consequências judiciais que levam à denúncia de uma prática que está se tornando corriqueira nas organizações, demonstrando a realidade vivenciada por alguns empregados que sofrem assédio moral.

\section{CONCLUSÕES}

Um ambiente de trabalho sadio é fruto das pessoas que nele estão inseridas, as quais se integram em um relacionamento pessoal, num entrosamento social, numa motivação e em união de forças, com o objetivo de chegarem a um bem comum: o bom resultado da empresa e a realização pessoal. Nesse sentido, pode-se afirmar que a qualidade do ambiente de trabalho, sob o aspecto pessoal, é muito mais do que relacionamentos meramente produtivos.

$\mathrm{Na}$ medida em o trabalho assume cada vez mais centralidade da vida do indivíduo o seu pertencimento a um grupo, no qual ele possa desenvolver e demonstrar a sua capacidade de criação e realização torna-se cruciais (BARRETO et al., 2009, p.9). Essa integração, todavia, fica irremediavelmente comprometida quando os empregados se sentem coisificados, despersonificados, perseguidos, desmotivados e assediados moralmente (BARRETO \& 2006; HIRIGOYEN, 2002; GUEDES, 2008).

Neste estudo, ficou constatado que o assédio moral ocorre nas organizações, e agride o ambiente de trabalho, de forma a degradar a vítima em seu aspecto psicológico. O sujeito perverso/assediador age de forma cruel, fria e calculista, de maneira a envolver o assediado em um jogo de manipulação. Essas agressões são visíveis nos julgados, nos quais ainda se verificaram as zombarias, comentários depreciativos, críticas hostis, risos de deboche, desmoralização e xingamentos públicos e repetidos. Pessoas que possuem a necessidade de se manter no emprego, de ficar no posto de trabalho, acabam por se sujeitar às mais diversas humilhações. Elas adoecem, primeiro, psicologicamente e, depois, fisicamente. Passam por um processo em que são acusadas por um ato que não cometeram, como o relatado no livro $O$ Processo, de Frank Kafka, em que Joseph K. Foi acusado de um crime e sentenciado à morte, embora sequer soubesse qual o crime e quem eram os seus acusadores (KAFKA, 1998). 
O assediador está caracterizado na figura do superior hierárquico que submete seus subordinados a maus-tratos, desmandos, humilhações, vexames e constrangimentos contínuos e habituais em seu ambiente de trabalho. Este tipo de assédio denominado vertical descendente é o mais comum nas organizações, como ficou caracterizado pelos ministros do Tribunal Superior do Trabalho. A gravidade do assédio moral no trabalho é de responsabilidade jurídica do empregador, conforme se comprovou nesta pesquisa. Mesmo com poucas leis específicas sobre o assunto, os ministros não deixaram de caracterizá-lo, já que o fizeram de forma minuciosa, com todas as características do fenômeno, de modo que o assédio se enquadra numa espécie do gênero dano moral, reconhecido pela Constituição da República de 1988.

A intensificação do assédio pode levar ao isolamento da vítima, como forma de autoproteção, o que posteriormente a leva a ser considerada pelos próprios colegas como antissocial e sem espírito de cooperação e, ainda, "pode provocar uma destruição da identidade e influenciar por muito tempo o temperamento da pessoa" (HIRIGOYEN, 2011, p.174). De tudo isso se conclui que o assédio moral, inevitavelmente, instala um clima desfavorável nas organizações, tanto de tensão entre os empregados quanto de apreensão e de competição. Ficou comprovado que o fator tempo de agressão é que caracteriza o assédio moral, imprimindo maior credibilidade ao conjunto probatório de fatos demonstrados nos julgados pesquisados.

O que se observa é que um superior hierárquico de personalidade exigente, meticulosa, que exige a excelência do trabalho ou determinado comportamento profissional, não pode ser visto como agressor, porquanto sua conduta insere-se entre as prerrogativas de seu poder diretivo e disciplinar. Contudo, se o superior abusar desse poder diretivo com frequência e, intencionalmente, prejudicar um empregado, o assédio moral se instala, como verificado nesta pesquisa.

O assédio moral prejudica a empresa, pois o empregado assediado, quando conhece o fenômeno, interpõe uma ação judicial cobrando os danos que sofreu por algum gestor perverso. A ação judicial é possível porque advém do contrato de trabalho realizado entre o empregado e empregador. Assim, caso haja confirmação do assédio moral, é a empresa que vai arcar com a indenização para com a vítima. Dessa forma, a prevenção e a orientação sobre o assédio moral constituem a melhor solução para o combate ao fenômeno, como esclarece Marie-France Hirigoyen (2002):

[...] a prevenção passa também pela educação dos responsáveis, ensinando-os a levar em conta a pessoa humana, tanto quanto a produtividade. Em cursos de formação específica, a serem dados por psicólogos ou psiquiatras formados em vitimologia, poder-se-ia ensiná-los a 'metacomunicar', isto é, a comunicar sobre a comunicação, a fim de que eles saibam intervir antes que o processo se instale, fazendo dar nome ao que no outro irrita o agressor, fazendo-o 'ouvir' o ressentimento de sua vítima (HIRIGOYEN, 2002).

O que ficou constatado na proposta deste estudo é que se confirmam as prerrogativas utilizadas pelos autores que norteiam o conceito e as características do assédio moral. Como o empregado foi vítima de práticas humilhantes ou vexatórias de um superior hierárquico ou, 
mesmo, de colegas, de modo a ter comprometidos seu bem-estar e sua saúde física ou mental, é preciso que exista uma atenção permanente por parte dos gestores e que os fatores culturais que fortalecem as formas de preconceitos sejam observados e combatidos.

$\mathrm{O}$ assédio moral dissemina-se tanto mais quanto mais desorganizada e desestruturada for a organização ou, ainda, quando o empregador finge não vê-lo, tolera-o ou, até mesmo, o encoraja. Outros sim, instala-se, especialmente, "quando o diálogo é impossível e a palavra daquele que é agredido não consegue fazer-se ouvir" (HIRIGOYEN, 2002). Isso ficou claro neste estudo. Por meio do material colhido e analisado, ficaram evidenciados vários fatores que possibilitem compreender as implicações do assédio moral nas três esferas analisadas: a individual, a organizacional e a social.

Esta pesquisa não esgota o tema; pelo contrário, abre espaço para ampliar as discussões. Espera-se, em primeiro lugar, que leve os gestores das organizações a refletirem sobre a forma de conduta de trabalho, seus métodos de gestão de pessoal e se esses métodos estão sendo suficientes para eliminar este malefício que é o assédio moral. Neste particular, é imperioso que a direção admita que o problema possa estar efetivamente ocorrendo no âmbito da empresa, acompanhando, de outra parte, o modo como as chefias intermediárias cobram os resultados das tarefas de seus empregados, a fim de reduzir os riscos de abuso de poder. Pois, como se verificou nesta pesquisa, os ministros do Tribunal Superior do Trabalho estão atentos ao assédio moral nas empresas e caracterizando o fenômeno e identificando quais são os comportamentos abusivos por parte dos gestores e, até mesmo, dos colegas de trabalho.

Conclui-se que o assédio moral é um processo composto de diferentes tipos de comportamentos os quais evoluem ao longo do tempo, e que, como analisado, poderia ser evitado e, consequentemente, afastado do ambiente do trabalho se os gestores ficassem mais atentos aos primeiros sinais da manifestação e tomassem atitudes capazes de coibir o fenômeno, pois um de seus resultados são as ações na Justiça do Trabalho.

No encerramento deste estudo, registra-se a importância do tema analisado para a cultura organizacional brasileira no que tange a suas variáveis. Por isso, é preciso prosseguir com outros trabalhos acadêmicos, principalmente para demonstrar o erro de se omitir quando se trata de assédio moral no trabalho. Como sugestão para futuras pesquisas, espera-se que sejam realizados estudos com diversas categorias de trabalhadores visando identificar e solucionar os problemas advindos do assédio moral. Assim, com a divulgação do termo 'Assédio moral' o empregado poderá, cada vez mais, buscar os seus direitos na Justiça do Trabalho. Também se torna relevante, na medida em que, os gestores conhecendo melhor o assunto poderão eliminar as formas de assédio moral naquela organização.

\section{REFERÊNCIAS}

AGUIAR, A. L. S.. Assédio moral nas organizações: estudo de casos dos empregados demitidos e em litígio judicial trabalhista no Estado da Bahia, 2003. Dissertação (Mestrado em Administração Estratégica) UNIFACS, Salvador, 2003. 
ANDRADE, J. O.. As carreiras femininas no espaço contemporâneo: trajetórias e perspectivas de mulheres profissionais brasileiras. Dissertação (Mestrado em Administração) - Universidade Federal de Minas Gerais, 2012.

ANDRADE, A.; Jackeline, D.; TITO, F. R. C.. Estruturação Intersubjetiva do Assédio Moral: Um Estudo do Contexto das Organizações Bancária. Revista Organizações em Contexto, V.8, p.1-12, 2012.

ARENAS, M. V. S.. Assédio moral e saúde no trabalho do servidor público do judiciário: implicações psicossociais. Tese (Doutorado em Administração) - Universidade Federal do Rio Grande do Sul, Porto Alegre, 2013.

BACCHI, G. A.. Entre o tripalium e a resiliência: um estudo sobre a correlação entre o assédio moral e a resiliência. Dissertação (Mestrado em Administração) - Fundação Universidade Estadual do Ceará, Fortaleza, 2011.

BARDIN, L.. Análise de conteúdo. São Paulo: Edições 70, 2006.

BARRETO, M. M. S.. Violência, saúde, trabalho: uma jornada de humilhações. São Paulo: EDUC/PUCSP, 2006.

BARRETO, M.; FREITAS, M. E.; HELONI, R.. Assédio Moral no Trabalho. São Paulo: CENGAGE LEARNING, 2009.

BARROS, A. M.. Curso de direito do trabalho. São Paulo: LTR, 2005.

BERNARDES, C.; MARCONDES, R. C.. Teoria Geral da Administração: gerenciando organizações. 3 ed. revisada e ampliada. São Paulo: SARAIVA, 2003.

BRASIL. Constituição (1988). Constituição da República Federativa do Brasil de, 1988. Brasília: Senado Federal, 1988.

BRASIL. Presidência da República. Casa Civil. Decreto-Lei $n^{\circ}$ 5.452, de $1^{\circ}$ de maio de 1943: CLT. Aprova a Consolidação das Leis do Trabalho.

BRASIL, Tribunal Superior do Trabalho. Jurisprudência consolidada. 2013.

CAHÚ, G. P. R.. Situações de assédio moral vivenciadas por enfermeiros no ambiente de trabalho. Dissertação (Mestrado em Enfermagem) - Universidade Federal da Paraíba, João Pessoa, 2012.

CAIXETA, I. C. C.. O assédio moral nas organizações: um estudo nos Tribunais Regionais do Trabalho das regiões Sudeste e Sul do Brasil. Dissertação (Mestrado em Administração) - Faculdade Novos Horizontes, Belo Horizonte, 2010.

CANIATO, A. M. P.; LIMA, E. C.. Assédio moral nas organizações de trabalho: perversão e sofrimento. Caderno Psicologia Social do Trabalho. São Paulo, v.11, n.2, 2008.

CARAN, V. C. S.; SECCO, I. A. O.; BARBOSA, D. A.; ROBAZZI, M. L. C. C.. Assédio moral entre docentes de instituição pública de ensino superior do Brasil. Dissertação (Mestrado em Enfermagem) Universidade de São Paulo, São Paulo, 2010.

CARNEIRO, M. P.. Juventude e movimento estudantil: o trabalho precário dos estudantes-bolsistas da UFES. Dissertação (Mestrado em Administração) - Universidade Federal do Espírito Santo, Vitoria, 2011.

CAVALCANTI, A. K. S.. Assédio Moral e limites ao poder disciplinar do empregador. Prima Facie internacional Journal, v.4, n.7, p.96-108, 2005.

CERVO, A. L.; BERVIAN, P. A.. Metodologia científica. 5 ed. São Paulo: Pearson Prentice Hall, 2002.

CORRÊA, A. M. H.; CARRIERI, A. P.. Assédio moral no ambiente de trabalho: uma Possibilidade de $(\mathrm{Re})$ leitura das Relações de Poder. In: ENCONTRO DA ASSOCIAÇÃO NACIONAL DE PÓSGRADUA ÇÃO E PESQUISA EM ADMINISTRAÇÃO, 29. Anais. Rio de Janeiro: ANPAD, 2005. 
COUTINHO, M. L. P.. Assédio moral no trabalho. Justiça do Trabalho, v.21, n.248, 2004.

DEJOURS, C.. A loucura do trabalho: estudo de psicopatologia do trabalho. 5 ed. São Paulo: Cortez, 1992.

ELGENNENI, S. M. M.; VERCESI, C.. Assédio moral no trabalho: implicações individuais, organizacionais e sociais. Revista Report Psicologia, v.9, n.1, p.68-95, 2009.

FEIJÓ, C.. A fixação de valores para dano moral. 2012

FERREIRA, J. B.. Nem tudo são flores nesse mar de rosas: um olhar sobre o Hospital do Câncer de Uberlândia. Dissertação (Mestrado em Administração) - Universidade Federal de Uberlândia, Belo Horizonte, 2010.

FLICK, U.. Qualidade na pesquisa qualitativa. Porto Alegre: Artmed, 2008.

FONTES, K. B.; PELLOSO, S. M.; CARVALHO, M. D. B.. Tendência dos estudos sobre assédio moral e trabalhadores de enfermagem. Revista Gaúcha de Enfermagem, v.32, p.815-822, 2011.

FREITAS. M. E.. Assédio Moral e Assédio sexual: faces do poder perverso nas organizações. RAE Revista de Administração de Empresas, São Paulo, v.41, n.2, p.8-19, 2001.

FREITAS. M. E.. Cultura organizacional: identidade, sedução e carisma?. 4 ed. Rio de Janeiro: Editora FGV, 2005.

FREITAS, M. E.. Gestão contemporânea está doente?. Qualidade de vida e fadiga institucional. Campinas: IPESI, 2006.

FREITAS, M. E.. Quem paga a conta do assédio moral do trabalhador?. RAE - Eletrônica, São Paulo, v.6, n.1, 2007.

FURTADO, R. A.. A construção e a (tentativa de) desconstrução da Cultura Usiminas: narrativas ao longo de 50 anos. Tese (Doutorado em Administração) - Universidade Federal de Minas Gerais, 2011.

GALVÃO, V. K.. O sistema brasileiro de repressão ao assédio moral no ambiente de trabalho.

Dissertação (Mestrado em Direito) - Universidade Federal de Alagoas, Maceió, 2011.

GARCIA, I. S.; TOLFO, S. R.. Assédio moral no trabalho: culpa e vergonha pela humilhação social. São Paulo: Juruá, 2011.

GARCIA I. S.; TOLFO, S. R.. Assédio moral no trabalho: uma responsabilidade coletiva Moral. Psicologia \& Sociedade, v.23, p.190-201, 2011.

GARCIA, G. F. B.. Curso de direito do trabalho. 4 ed. Rio de Janeiro: Forense, 2010.

GIL, A. C.. Como elaborar projetos de pesquisa. São Paulo: Atlas, 1991.

GUEDES, M. N.. Terror psicológico no trabalho. 3 ed. São Paulo: LTR, 2008.

HIRIGOYEN, M. F.. Assédio moral: a violência perversa no cotidiano. 7 ed. Rio de Janeiro: Bertrand, 2002.

HIRIGOYEN M. F.. Mal-estar no trabalho: redefinindo o assédio moral. 6 ed. Rio de Janeiro: Bertrand Brasil, 2011.

HELOANI, R.. Assédio moral: um ensaio sobre a expropriação da dignidade do trabalho. RAE-Eletrônica, v. 3, n.1, 2004.

KAFAK, F.. O Processo. São Paulo: Companhia das Letras, 1998.

LAKATOS, E. M.; MARCONI, M. A.. Fundamentos de metodologia científica. 5 ed. São Paulo: Atlas, 2003. 
LAKATOS, E. M.; MARCONI, M. A.. Técnica de pesquisa, amostragem e técnica de pesquisa, elaboração, analise e interpretação de dados. 6 ed. São Paulo: Atlas, 2007.

LEYMANN, H.. Mobbing and psychological terror at workplaces. Violence and Victims, v.5, n.2, p .119126, 1990.

MARCONI, M. A.; LAKATOS, E. M.. Técnica de pesquisa. 6 ed. São Paulo: Atlas, 2007.

MARTINS, S.. Direito do trabalho. 20 ed. São Paulo, Atlas, 2004.

MARTINS, W.. Assédio moral: uma violência estratégica. Dissertação (Mestrado de Gestão de Negócios) Universidade Católica de Santos, Santos, 2010.

MENDONÇA, J. M. B.. Relações que dilaceram oportunidades: o espaço invisível entre o eu e o outro. Dissertação (Mestrado em Administração) - Universidade Federal de Minas Gerais, Uberlândia, 2013.

MINAS GERAIS. Governo do Estado de Minas Gerais. Assembleia Legistativa. Lei Complementar n. 117, de 11 de janeiro de 2011. Dispõe sobre a prevenção e a punição do assédio moral na administração pública estadual de Minas Gerais.

MOURA, M. A.. Assédio moral. Juiz de fora: 2012.

MEURER B.; STREY, M. N.. Problematizando as práticas psicológicas no modo de compreender o fenômeno assédio moral. Psicologia: Ciência e Profissão, v.32, p.452-433, 2012.

NOVELINO, M.. Direito constitucional. 3ed. Rio de Janeiro: Forense, 2009.

NUNES, T. S.; TOLFO, S. R.. Assédio moral organizacional: fatores organizacionais propiciadores e a dinâmica do assédio. In: ENCONTRO DA ASSOCIAÇÃO NACIONAL DE PÓS-GRADUAÇÃO E PESQUISA EM ADMINISTRAÇÃO, 35. Anais. Rio de Janeiro: ANPAD, 2011.

PELI, P.; TEIXEIRA, P.. Assédio moral: uma responsabilidade corporativa. São Paulo: ÍCONE, 2006.

RICHARDSON, R. J.. Pesquisa Social Métodos e Técnicas. 7 ed. São Paulo: Atlas, 2007.

RODRIGUES M.. Estudos sobre assédio moral no Brasil: uma análise sobre caminhos percorridos In: Seminário em Administração.18. Anais. Rio de Janeiro: SemeAd, 2010.

SANTOS, F. M. A.; SIQUEIRA, M. V. S.; MENDES, A. M.. Tentativas de suicídio de bancários no contexto das reestruturações produtivas. Revista de Administração Contemporânea - RAC, v.14, p.925-936, 2010.

SARAIVA, R.. Direito do trabalho. 2 ed. Rio de Janeiro: Forense, 2009.

SCHWARZ, R. G.. Direito do trabalho. Rio de Janeiro: Elsevier, 2007.

SILVA, R. O.. Teoria da Administração. São Paulo: Pioneira Thomson Learning, 2004.

SIQUEIRA, M. V. S.; MENDES, A. M.. Os desafios em ser sujeito no âmbito da gestão de pessoas nas organizações contemporâneas. In: ENCONTRO DA ASSOCIAÇÃO NACIONAL DE PÓS-GRADUAÇÃO E PESQUISA EM ADMINISTRAÇÃO, 35. Anais. Rio de Janeiro: ANPAD, 2011.

SOSSELA, M. L.; NEVES, E. B.. As consequências do assédio moral para trabalhadores, organização e governo. Revista Uniandrade, v.12, p.17-22, 2011.

TRIVIÑOS, A. N. S.. Introdução à pesquisa em ciências sociais: a pesquisa qualitativa em educação. São Paulo: Atlas,1987.

TURTE, S. L.. Violência psicológica e assédio moral no trabalho: percepção e estratégias de enfrentamento de adolescentes trabalhadores. Dissertação (Mestrado em Saúde Pública) - Universidade de São Paulo, São Paulo, 2012.

VERGARA, S. C.. Projetos e Relatórios de Pesquisa em Administração métodos de pesquisa em administração. 6 ed. São Paulo: Atlas, 2005. 
VERGARA, S. C.. Métodos de pesquisa em administração. 2 ed. São Paulo: Atlas, 2006.

YUNG, R. W.. Assédio moral no trabalho, suas formas de expressão e as repercussões nas diversas áreas da vida. Dissertação (Mestrado em Saúde) - Universidade do Vale do Itajaí, Itajaí, 2011. 